\title{
REFINEMENT METHOD OF RETAINING WALL (L-SHAPE CONCRETE) AND CCSP DESIGN IN KALIMAS QUAYSIDE KADEMETER 1200-1400 PROJECT
}

\author{
Margantionius \\ Margantionius@pelindo.co.id \\ Civil Engineering Study Program \\ Narotama University Surabaya \\ Jalan Arif Rahman Hakim 51, Sukolilo, Surabaya \\ Ronny Durrotun Nasihien \\ Ronny.durrotun@narotama.ac.id \\ Civil Engineering Study Program \\ Narotama University Surabaya \\ Jalan Arif Rahman Hakim 51, Sukolilo, Surabaya
}

\begin{abstract}
As one of the state-owned enterprises (BUMN), PT Pelabuhan Indonesia III (Persero) Regional Jawa Timur has demanded to obtain the considerable revenues using the limited maintenance funds for port facilities. One of the roles of Engineering Division includes the availability of port facilities that support operation division, so it is necessary to check and maintain the facilities. In consequence, the estimated cost and time of project carried out effectively to mitigate the risk level in the future in order to achieve the main objectives. One of the biggest revenues in the port sector is on the quayside facility services, therefore, maintenance of these facilities needs to be prioritized. The final project provides an analysis of cost and time calculations using the method of repairing the retaining wall (L-Shape Concrete) and the CCSP (Coruggated Concrete Sheet Pile) method for repairing damage to Kalimas Kademeter Quayside 1200-1400 with damage length of 176 meters and width of 9 meters. Based on the observation of cost and time analysis, the estimated cost of using the L-Shape Concrete repair method is much cheaper than using the CCSP (Coruggated Concrete Sheet Pile) method, but the actual project period is much longer. Finally, the selection of repair methods can adjust to the necessity of cost and time aspects, as well as the methods of project.
\end{abstract}

Keywords : Quayside repair method, cost and time analysis

\section{INTRODUCTION}

Tanjung Perak Port as the main port, has a very strategic role and function, which is as a support to facilitate the continuity of sea transportation and as the prime mover to increase the economic growth, particularly in East Java and generally in Eastern Indonesia (KTI). In addition, the Port of Tanjung Perak is also a port of Transhipment (transfer of goods) from Eastern Indonesia for both international and domestic seaborne trade purposes or vice versa. PT Pelabuhan Indonesia III (Persero) The East Java Regional has owned some land in Surabaya Kalimas Terminal Port. Currently, the area has served as a local port, warehousing, container depots and offices. The development of economic activities and trade activities in the Kalimas Quayside is growing rapid ly and is starting to develop where the traffic of goods through the port of Tanjung Perak, this can be indicated that not only basic food items but also building material commodities such as cement, construction irons and piles and others. The Quayside of Kalimas Terminal is a traditional jetty with increasingly crowded activity levels. Conventional loading and unloading activities, tidal water circumstances and old jetty conditions are the root cause of quayside disintegration. The selection of methods for improvements 
Volume 03 Number 01 September 2019

implemented to a construction project is very important because the right implementation methods can provide maximum results, especially if viewed in terms of cost and time. One of the efforts undertaken by the project manager is to replace conventional methods to become more modern, namely by applying precast concrete.

Based on the description above, the problem that can be taken such as:

1. Observing a more efficient quayside damage repair method between the L-Shape Concrete method and the CCSP erection in terms of construction costs;

2. Observing a more efficient quayside damage repair method between the L-Shape Concrete method and the CCSP erection in terms of construction costs;

3. Observing the repair method that is the most efficient in terms of cost and time so that it can be applied to the repair project of Kalimas P Quayside of the Port of Indonesia III (Persero) East Java Regional.

There are various methods for repairing damaged docks, but in this study is to compare the effectiveness of the use of methods to repair the retaining wall (L-Shape Concrete) and CCSP design (Coruggated Concrete Sheet Pile).

a. CCSP (Coruggated Concrete Sheet Pile)

CCSP serves as a foundation on the structure of the building above it to channel the gravity of the building to hard soil that is very far below the surface of the soil. CCSP can function as a pile, that is if it is designed, it will form a retaining wall that can hold water, or landslide.

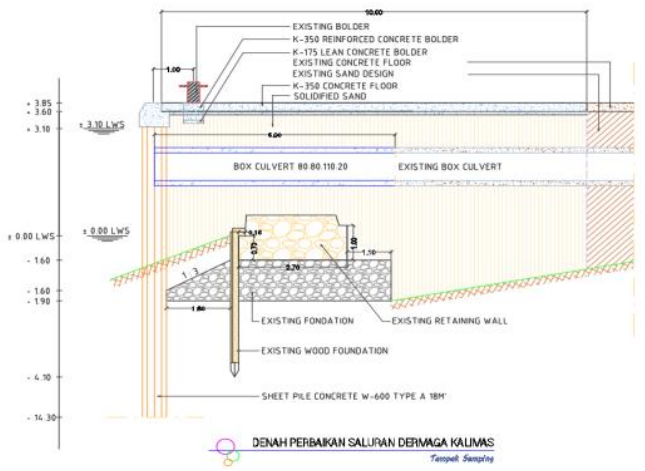

Figure 1. Refinement Method of CCSP in Kalimas Quayside Project

b. Retaining wall (L-Shape Concrete)

Retaining wall is a construction that is usually made of reinforced concrete that serves to hold natural soil or loose soil and prevent the collapse of sloping land or slopes whose stability cannot be guaranteed by the slope of the ground itself so as to prevent from danger of landslides both due to rain water loads, the weight of the land itself and due to the burden of working on it.

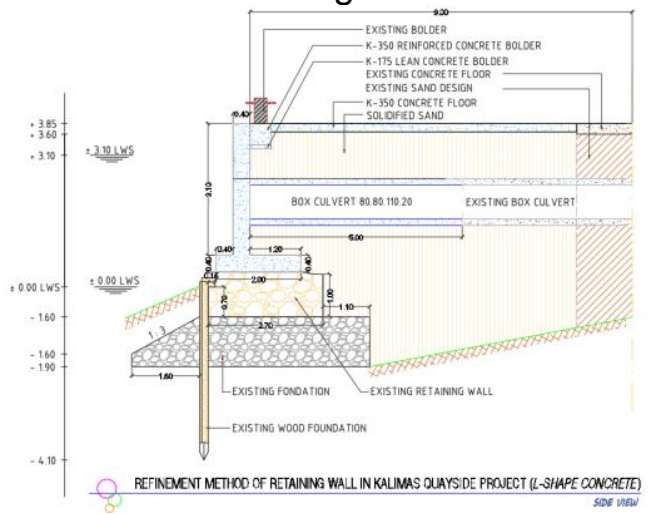

Figure 2. Refinement Method of Retaining Wall in Kalimas Quayside Project 
Volume 03 Number 01 September 2019

The explanation regarding the pier repair method used in this study is as follows:

Table 1. Literature Review

\begin{tabular}{|c|c|c|}
\hline No & Author & Recearch Material \\
\hline 1. & $\begin{array}{l}\text { Alya } \\
\text { Risdayanti } \\
\text { (UWKS - } \\
\text { 2018) }\end{array}$ & $\begin{array}{l}\text { Comparing the } \\
\text { effectiveness of using } \\
\text { conventional methods and } \\
\text { precast methods in terms } \\
\text { of cost and time, a case } \\
\text { study on the Mayjend } \\
\text { Sungkono Surabaya } \\
\text { Satellite Overpass and } \\
\text { Underpass Development } \\
\text { Project }\end{array}$ \\
\hline 2. & $\begin{array}{l}\text { Didiet } \\
\text { Adhytiya } \\
\text { (ITS-2014) }\end{array}$ & $\begin{array}{lr}\text { Alternative } & \text { planning of } \\
\text { Mayjen } & \text { Sungkono } \\
\text { Surabaya } & \text { Underpass } \\
\text { retaining wall } & \end{array}$ \\
\hline
\end{tabular}

Data analysis is carried out in the form of an analysis of the budget plan and analysis of the time of project implementation, where:

1. Analysis of the RAB using the 2017 HSPK analysis;

2. Analysis of the implementation time is calculated from the project began to decrease / slender material components in the project location.

The alternative selection of retaining wall chosen for underpass is secant pile, because it has a lower cost, but other factors that also influence besides the low cost factor are the strength factor and ease of implementation factors that can be used as other considerations in determining alternatives.

3. Isti Radhista Planning for Pile Wall From the results of gravity wall stability Hahamany Sheet Construction as an (Yogyakarta Alternative to Gravity Wall University of Replacement Technology analysis, it can be concluded that when the structure receives a static load, the stability of the construction is not safe from overtuning, sliding, pressure effects, and broken legs, but it is still safe to receive the effects of shear and stability of carrying capacity is met. When burdened by dynamic loads during implementation, the structure is safe from rolling, sliding and carrying capacity of the soil.

4. Djoni Irianto Designing Corrugated The results of observations on the (Unesa - Concrete Sheet Pile 2014) (CCSP) at Wonokromo River Improvement Surabaya Project Surabaya Wonokromo River Improvement (Wonokromo River) Sub-project (Package3) project, there are several things as suggestions that the author can convey are as follows:

a. Coordinate with project implementers about what project will be carried out;

b. Get a lot of information to the planners and implementers;

c. Place the CCSP in a shady location so as not to reduce the quality of the stake.

5. Septiana The stability of the Widi Astuti Corrugated Concrete (Building and Sheet Pile (CCSP) of the Railroad Soil Retaining Wall at the Engineering, Abutmen Bridge Bh 1751 Indonesian in the Ulo Location District, Railroad Kebumen.

Based on the results of the analysis of the stability of Corrugated Concrete Sheet Pile (CCSP), it was concluded that:

a. CCSP with $18 \mathrm{~m}$ depth has a safety score of 0.9 so it does not meet the stability requirements because the security value is less than 1 : 
Volume 03 Number 01 September 2019

\begin{tabular}{|c|c|c|c|}
\hline & $\begin{array}{l}\text { Madiun } \\
\text { 2019) }\end{array}$ & & $\begin{array}{l}\text { score of } 1.3 \text { so it meets the stability } \\
\text { requirements with a security value of } \\
\text { more than } 1 \text {. }\end{array}$ \\
\hline 6. & $\begin{array}{l}\text { Hatwan } \\
\text { Fardilla } \\
\text { (University of } \\
\text { Lampung - } \\
\text { 2018) }\end{array}$ & $\begin{array}{l}\text { Retaining Wall Planning as } \\
\text { an Alternative to } \\
\text { Preventing Landslides in } \\
\text { Bridge Construction. }\end{array}$ & $\begin{array}{l}\text { From the results of the analysis and } \\
\text { calculations carried out by researchers, the } \\
\text { following conclusions are drawn: } \\
\text { a. Perform the calculation of the } \\
\text { dimensions of the retaining wall so that } \\
\text { it is safe and able to hold the soil back } \\
\text { on the bridge oprit from the landslide; } \\
\text { b. Perform calculations of the structure of } \\
\text { the vertical wall and leg wall } \\
\text { reinforcement to hold the moment on the } \\
\text { wall. }\end{array}$ \\
\hline
\end{tabular}

\section{RESEARCH METHOD}

The designated diagram of the final project according to the Flowchart methodology is as follows:

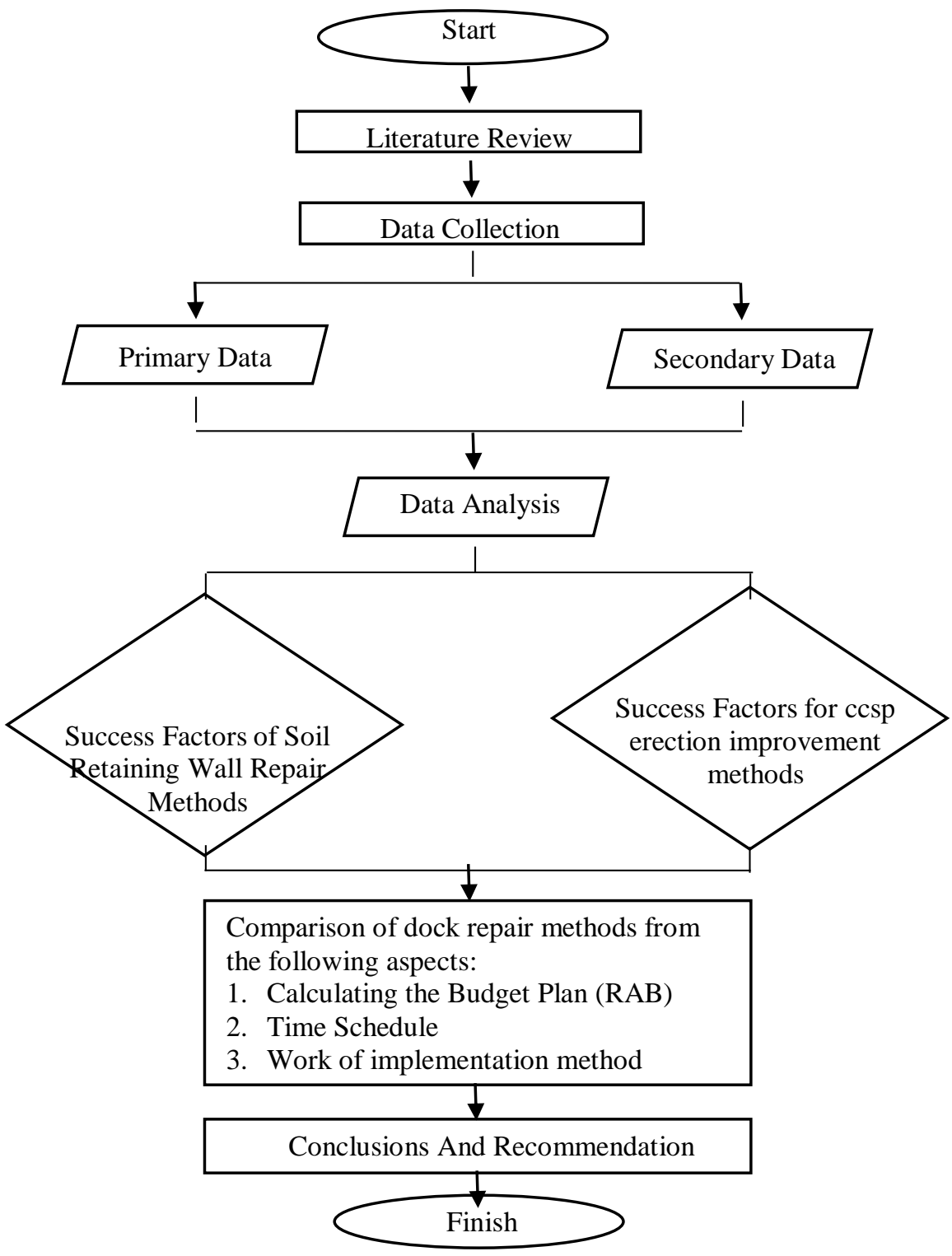


Volume 03 Number 01 September 2019

Analysis of the data used in this discussion is the analysis of the calculation of the estimated cost of project using the analysis of the unit price of project (Surabaya city HSPK in 2018) to produce a cost savings to taking into account the estimated cost and implementation time using the retaining wall repair method ( $\mathrm{L}$-Shape Concrete) and CCSP (Coruggated Concrete Sheet Pile) erection on the project of Kalimas Kademeter Quayside 1200-1400. Analysis of the calculation of the estimated cost and implementation time is carried out in several stages, as follows:

a. Phase of project volume calculation;

b. Phase analysis of the project coefficient;

c. Phase analysis of project unit prices;

d. Phase of calculating the Budget Plan (RAB) and recommendations.

$R A B=\Sigma[($ Volume $) x$ Job Unit Price $]$.

\section{RESULTS AND DISCUSSION}

After calculating the cost estimation and time by comparing the two methods that have been discussed for the implementation of damage repair project Kalimas Quayside Kermeter 1200-1400 with damage area length $=176 \mathrm{~m}$ 'and 9m width' according to the table as follows:

Table 4.1 Results of Comparative Analysis of Refinement Methods in Kalimas Quayside

\begin{tabular}{|c|c|c|c|}
\hline $\begin{array}{c}\text { Quayside } \\
\text { Repair Method }\end{array}$ & $\begin{array}{c}\text { Retaining Wall Design } \\
(L-S h a p e \text { Concrete }) \\
\text { Quayside Repair along } \\
\text { the } 176 \text { meters and } 9 \\
\text { meters wide }\end{array}$ & $\begin{array}{c}\text { CCSP Design } \\
\text { Quayside Repair along } \\
\text { the } 176 \text { meters and } 9 \\
\text { meters wide }\end{array}$ & Terms \\
\hline Cost Estimation & $\begin{array}{l}\text { Rp.5.581.287.800 } \\
\text { (inclued PPN 10\%) }\end{array}$ & $\begin{array}{l}\text { Rp.12.520.840.200 } \\
\text { (inclued PPN 10\%) }\end{array}$ & \\
\hline Execution time & 180 days & 120 days & \\
\hline $\begin{array}{l}\text { Moment } \\
\text { Control of } \\
\text { bolsters }\end{array}$ & 5,67 & - & $\begin{array}{l}5,67>1,5 \\
(\mathrm{OK})\end{array}$ \\
\hline Momen Crack & - & 51,6 ton.m & $\begin{array}{c}51,6 \mathrm{t} . \mathrm{m}>50,6 \mathrm{t} . \mathrm{m} \\
(\mathrm{OK})\end{array}$ \\
\hline $\begin{array}{l}\text { Dewatering } \\
\text { Method }\end{array}$ & Yes & No & \\
\hline
\end{tabular}

\section{CONCLUSIONS}

From the explanation above, the following conclusions can be described as follows :

1. The result of cost calculation and implementation time for the Kalimas quayside refinement project as below :

- On the one hand, Cost estimation of the L-Shape Concrete method is Rp. $5,581,287,800$ with a duration of 180 days;

- On the other hand, cost estimation of CCSP erection method is Rp. $12,520,840,200$ with a project period of 120 days;

2. Ease of implementation and occupational safety factors using the CCSP design method can also be taken into consideration for the selection of improvement methods;

3. Further research needs to be done related to the durability of construction to soil conditions over a period of years except for the quayside repair;

4. Further research needs to be done related to structural calculations using either the 
Volume 03 Number 01 September 2019

L-Shape Concrete method or the CCSP erection method.

\section{REFERENCE}

Alya Risdiyanti, Siswoyo. (2018). Cost and Time Comparison Analysis Between Conventional and Preprinted Methods (Case Study: Underpass Satellite Mayjend Sungkono Surabaya Round about).

Brown, William D. (1994). Design Of Sheet Pile Walls, Design Of Sheet Pile Walls, pdf.

Djoni Irianto, Dwi Ratih Wewesa. (2013). Designing Corrugated Concrete Sheet Pile (CCSP) on Wonokromo River Improvement Project Surabaya Sub-Project Package3. Surabaya.

Didiet Adhytiya. (2014). Alternative Planning for Underwater Retaining Wall Mayjen Sungkono Surabaya.

Eka Setyowati. (2012). Plaster Construction Planning Instead of Retaining Walls (Case Study: Donggala Ring Road).

Hatwan Fardilla. (2018). Retaining Wall Planning as an Alternative to Preventing Landslides in Bridge Construction.

Hardiyatmo, H.C (a). (2002). Soil Mechanics I. Gadjah Mada University Press. Yogyakarta.

Hardiyatmo, H.C (b). (2003). Soil Mechanics II. Gadjah Mada University Press. Yogyakarta.

Hardiyatmo, H.C (c). (2006). Management of Landslides and Erosion. Gadjah Mada University Press. Yogyakarta.

Isti Radhista Hertiany. (2014). Construction Design Sheet Pile Wall As an Alternate Gravity Wall (Case Study Sindu Kusuma Edupark Project, Yogyakarta).

Martini, Shyama Maricar, Hendra Setiawan. (2012). Plaster Construction Planning Instead of Retaining Walls (Case Study Donggala Ring Road).

Septiana Widi Astuti. (2019). The stability of the Corrugated Concrete Sheet Pile (CCSP) of the Soil Retaining Wall at the Abutmen Bridge Bh 1751 in Lok Ulo District, Kebumen.

Smith, M.J. (1984). Soil Mechanics. Erlangga. Jakarta.

Wesley, Laurence D. (2012). Soil Mechanics For Sediment Soil And Residues. Andi. Yogyakarta. 